\title{
Adrenomedullin as a Potential Therapeutic Agent for Refractory Ulcerative Colitis
}

\author{
Kazuo Kitamura, Shinya Ashizuka, Haruhiko Inatsu, and Toshihiro Kita
}

\begin{abstract}
Adrenomedullin (AM) was originally isolated from human pheochromocytoma as a biologically active peptide with potent vasodilating action, but it also has a wide range of physiological properties including cardiovascular protection, neovascularization, and the ability to suppress apoptosis. It is constitutively produced by various tissues including the gastrointestinal tract. AM production and secretion can be induced by pro-inflammatory cytokines such as tumor necrosis factor- $\alpha$ and interleukin-1, as well as by lipopolysaccharide. Conversely, AM causes the downregulation of inflammatory cytokines in cultured cells and downregulates inflammatory processes in various models of colitis, including those induced by acetic acid and by dextran sulfate sodium. AM works by exerting anti-inflammatory and antibacterial effects and by stimulating mucosal regeneration and supporting maintenance of the colonic epithelial barrier. The present findings suggest that AM could serve as a novel agent for treating refractory ulcerative colitis.
\end{abstract}

Keywords Endogenous peptide - Inflammatory bowel disease - Autoimmune response $\bullet$ Cytokines $\bullet$ Translational research $\bullet$ Hypotensive peptide

\section{Abbreviations}

$\begin{array}{ll}\text { AM } & \text { Adrenomedullin } \\ \text { AZA } & \text { Azathioprine } \\ \text { CD } & \text { Crohn's disease } \\ \text { CGRP } & \text { Calcitonin gene related peptide } \\ \text { CRLR } & \text { Calcitonin receptor-like receptor } \\ \text { DSS } & \text { Dextran sulfate sodium } \\ \text { HIF } & \text { Hypoxia-induced factor } \\ \text { IBD } & \text { Inflammatory bowel disease }\end{array}$

K. Kitamura, M.D., Ph.D. $(\bowtie) \bullet$ S. Ashizuka • H. Inatsu • T. Kita Department of Internal Medicine, Circulatory and Body Fluid Regulation, Faculty of Medicine, University of Miyazaki, 5200 Kihara, Kiyotake, Miyazaki City, Miyazaki 889-1692, Japan

e-mail: kazuokit@med.miyazaki-u.ac.jp 


$\begin{array}{ll}\text { IELs } & \text { Intraepithelial T lymphocytes } \\ \text { IFN } & \text { Interferon } \\ \text { IL } & \text { Interleukin } \\ \text { iNOS } & \text { Inducible nitric oxide synthase } \\ \text { IR } & \text { Immunoreactive } \\ \text { LPS } & \text { Lipopolysaccharide } \\ \text { PAMP } & \text { Proadrenomedullin N-terminal } 20 \text { peptide } \\ \text { PSL } & \text { Prednisolone } \\ \text { RAMP } & \text { Receptor activity-modifying protein } \\ \text { STAT } & \text { Signal transducer and activator of transcription } \\ \text { TCR } & \text { T-cell receptor } \\ \text { TGF } & \text { Transforming growth factor } \\ \text { TNF } & \text { Tumor necrosis factor } \\ \text { UC } & \text { Ulcerative colitis } \\ \text { UCDAI } & \text { Ulcerative Colitis Disease Activity Index } \\ \text { VSMCs } & \text { Vascular smooth muscle cells }\end{array}$

\section{Introduction}

Inflammatory bowel disease (IBD) is a refractory ailment, probably involving an autoimmune response to one or more as yet unknown triggers in the intestinal tract. The etiology of IBD is unknown, but it is thought to involve genetic, immunological, and environmental factors. The two major types of IBD are ulcerative colitis (UC) and Crohn's disease (CD). An estimated 1.4 million persons are afflicted with these diseases in the USA $[1,2]$ and the estimated number of patients with IBD in Japan has recently increased to over 100,000 . Therefore, the number of patients with severe and refractory UC has also increased, and consequently, new and effective drugs for refractory UC are highly desirable.

Adrenomedullin (AM) was originally isolated from a human pheochromocytoma as a potent vasodilatory peptide that could elevate levels of platelet cAMP [3]. In addition to hypotension and other properties, AM regulates cellular growth and differentiation, stimulates angiogenesis, and modulates hormone secretion. AM also appears to inhibit inflammation and support tissue homeostasis by suppressing the synthesis of pro-inflammatory cytokines and promoting wound healing [4]. In fact, AM ameliorates several types of colitis induced in animal models, and because it is an endogenous biologically active peptide, it should be a safe and effective drug for the treatment of IBD.

This chapter presents general information about AM, its physiological and pathophysiological roles within gastrointestinal organs, and its therapeutic effects in animal models with colitis and in patients with refractory UC. 


\section{Basic Characteristics of AM}

AM is a biologically active peptide that was initially isolated from a human pheochromocytoma arising from the adrenal medulla [3]. The human AM gene is located at the distal end of the short arm of chromosome 11 (p15.1-3) [5]. The AM protein expressed in humans is composed of 52 amino acids (Fig. 1) and it belongs to the calcitonin peptide superfamily, which also includes calcitonin gene-related peptide (CGRP), amylin, and adrenomedullin-2/intermedin [6]. Functional AM or CGRP receptors comprise calcitonin receptor-like receptor (CRLR) and a receptor activity-modifying protein (RAMP) [7]. Three types of RAMP are expressed in mammalian tissue, and CRLR can function as either a CGRP receptor or an AM receptor, depending on the co-expressed RAMP subtype (Fig. 1).

The precursor of human AM (human preproAM) comprises 185 amino acids and includes the AM sequence [8]. In addition to AM, proadrenomedullin (proAM) contains a novel 20-residue peptide called proadrenomedullin N-terminal 20 peptide (PAMP), which is also processed from the AM precursor (Fig. 1), but PAMP is not discussed here.

$\mathrm{AM}$ is essentially ubiquitous in human tissues. Immunoreactive AM has been identified in cardiovascular, renal, respiratory, gastrointestinal, reproductive,

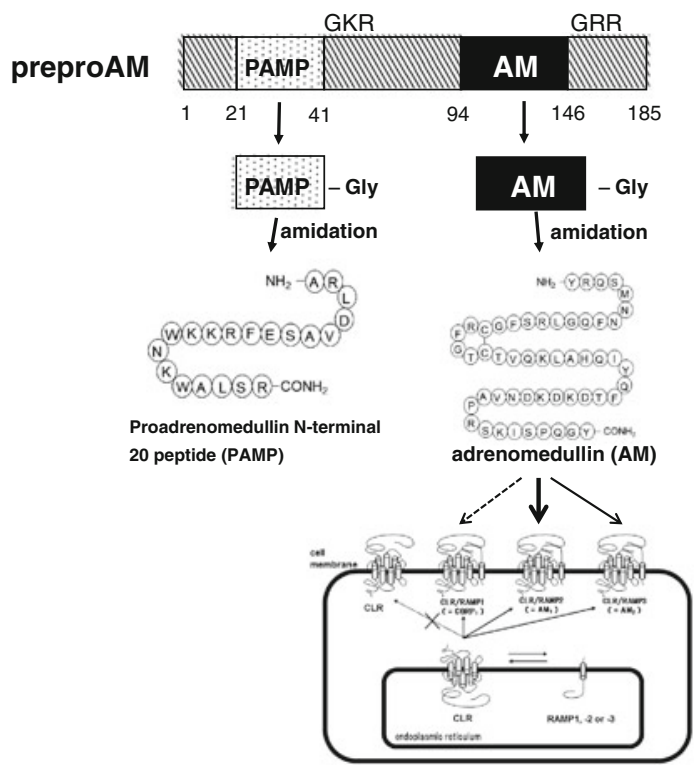

Fig. 1 Processing and biosynthesis of AM and PAMP from preproAM and relationships between $\mathrm{AM}$ and its receptor. When processed from preproAM, AM-Gly, an intermediate form (iAM), is produced and converted by an amidation enzyme to mature AM (mAM) with an amide structure at the C-terminal [8]. The mature form of PAMP is thought to be produced via a similar process. CRLR serves as a CGRP receptor when co-expressed with RAMP1, and as an AM type 1 or 2 (AM1 or AM2) receptor when co-expressed with either RAMP2 or RAMP3, respectively [7] 
neurological, endocrine, and immune tissues [9]. AM is produced in stromal as well as parenchymal cells, and numerous factors can influence its synthesis. For example, cardiovascular hormones such as angiotensin II and endothelin increase AM production in vascular smooth muscle cells (VSMCs). The production of AM is also regulated by physical factors such as shear stress, ventricular wall stress, and hypoxia, as well as by inflammatory cytokines such as tumor necrosis factor (TNF)- $\alpha$ and interleukin (IL)-1 [11]. Lipopolysaccharide (LPS) also stimulates the synthesis and secretion of AM in endothelial cells, VSMCs, and various other cell types [10].

AM has generally been characterized as a cardiovascular hormone. Consistent with such a classification, AM is an essential cardiovascular peptide involved in regulating the circulation and controlling body fluids. In addition, AM reportedly exerts angiogenic, lymphangiogenic, antioxidant, tissue protective and reparative, and anti-inflammatory effects. These multiple biological activities of AM have been described in two recent reviews $[4,11]$.

\section{Pathophysiological Roles of AM in Inflammation}

Plasma AM concentrations are elevated in patients with hypertension, congestive heart failure, myocardial infarction, or renal diseases, and during the acute phase of stroke [12-14]. Two molecular forms of AM circulate in the blood of humans and rats; one is a mature form of AM with an amidated C-terminal (AM-NH2), and the other is an intermediate form with a non-amidated C-terminal glycine (AM-Gly). Plasma and tissue AM concentrations have been measured in several studies, but most of them detected immunoreactive AM as total AM comprising AM-NH2 and AM-Gly $[12,13,15]$. Figure 2 shows a comparison of plasma mature and total AM concentrations in several diseases. Both mature and total AM levels in plasma are increased in arthritis and inflammatory bowel diseases in addition to hypertension and renal diseases.
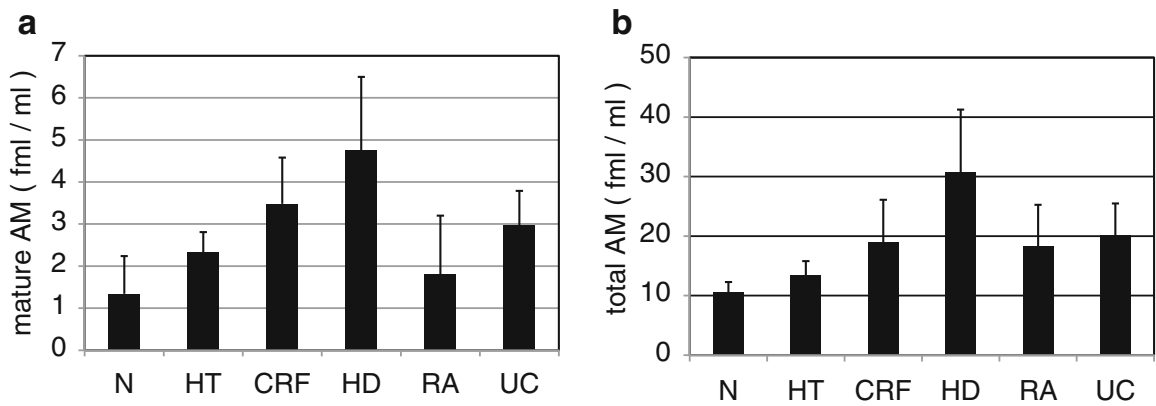

Fig. 2 Comparison of plasma concentrations of mature (a) and total(b) AM in healthy volunteers and patients with hypertension, renal failure, and inflammatory disorders (Modified and redrawn from Ohta et al. [12, 15]) 
Given its biological activity as a circulation control factor with potent hypotensive and natriuretic activity, elevated AM in cardiovascular disease might inhibit disease progression. Plasma AM concentrations are also increased in patients with septic shock [16, 17], and we also found high levels of plasma AM in patients with UC (Fig. 2). Pro-inflammatory cytokines such as TNF- $\alpha$ and IL-1, and LPS can induce AM synthesis. Conversely, AM causes the downregulation of inflammatory cytokines in Swiss 3 T3 fibroblasts [18] and rat alveolar macrophages [19]. In addition, AM possesses immunomodulatory activities that downregulate inflammatory processes in various models, including those of arthritis [20] and pancreatitis [21]. These findings suggest that beyond having vasorelaxant activity, AM might negatively regulate the inflammatory response. Consistent with this notion, AM secretion and plasma levels are both increased in models of endotoxic shock [22]. Furthermore, heterozygous AM knockout mice are significantly more sensitive to endotoxic shock than wild-type mice [23], whereas transgenic mice overexpressing AM are resistant to endotoxic shock [24]. Taken together, these findings suggest that AM is an anti-inflammatory peptide that exerts protective effects in the context of endotoxic shock and inflammatory disorders.

$\mathrm{AM}$ is also widely distributed in the gastrointestinal tract, and is expressed at high levels in the stomach and colon. Immunohistochemical analysis has revealed AM-immunoreactive (IR) cells in the pyloric glands, where they also stain positively for chromogranin A and gastrin [25]. AM-IR cells are also found in the mucosal and glandular epithelia of the digestive tract, as well as in the endocrine and neuroendocrine systems [9]. Tissues surrounding gastric ulcers stain intensely for AM [26], and $\mathrm{AM}$ expression in these regions tends to increase during the healing and scarring stages of gastric ulcers, suggesting that AM is involved in gastric mucosal healing. Indeed, AM has significant ulcer-healing activities in animal models of gastric ulcers $[27,28]$. The mechanism through which AM stimulates ulcer healing is presumed to involve the preservation of gastric blood flow, the inhibition of gastric acid secretion, the stimulation of angiogenesis, and the proliferation of mucosal epithelial cells. On the other hand, AM expression is increased in human colon cancer cells [29, 30]. Thus, AM may contribute to the pathogenesis of colon cancer through its ability to stimulate angiogenesis and cell proliferation.

\section{Preclinical Pharmacological Effect of AM in Experimental Model of Colitis}

As summarized above, AM apparently exerts anti-inflammatory effects by inhibiting the expression of TNF- $\alpha$ and IL- $1 \beta$, and it protects against experimentally induced ulcers of the gastric mucosa. AM immunoreactivity has been detected throughout the gastrointestinal tract, with concentrations being comparably high in the stomach and colon [25]. Although little is understood about the physiological and pathophysiological functions of AM in the gastrointestinal tract, these findings suggest that endogenously expressed AM in the colon could play an important 

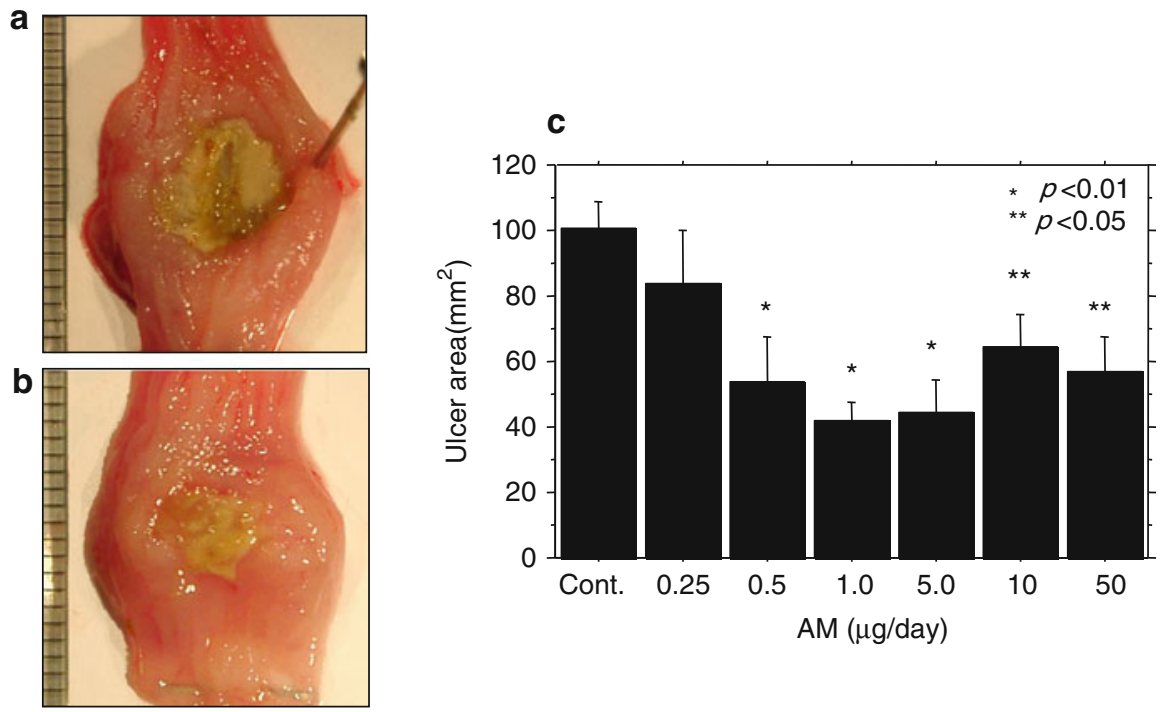

Fig. 3 Macroscopic and histological appearance of colonic ulcers induced by subserosal injection of acetic acid. Rats were treated with saline (a) or $\mathrm{AM}(\mathbf{b})$ for 5 days. Rats given AM had milder ulceration and less edema. Effects of AM $(0.25-50.0 \mu \mathrm{g} /$ day $)$ on acetic acid-induced colonic ulcers at 5 days after induction (c) ( $n=5$ per group). AM dose-dependently reduced the ulcer area, but this effect was diminished at higher doses (Modified and redrawn from Ashizuka et al. [31])

protective role against inflammatory bowel diseases. To test this hypothesis, we assessed the effect of synthetic AM on acetic acid-induced colitis and cytokine production [31]. Colitis was induced using the method of Kojima et al. [32], after which AM or saline was administered anally once a day for 3-10 days. The synthetic AM significantly reduced the size and severity of the ulcerative lesions and also reduced edema (Fig. 3a, b). Microscopically, less severe ulceration, reduced edema, and milder infiltration of the lamina propria by inflammatory cells were found in samples of colonic mucosa from rats treated with AM. Furthermore, IL-6 levels in the affected tissues were significantly lower in AM-treated rats than in control rats. On the other hand, AM did not significantly affect levels of interferon- $\gamma$ (IFN- $\gamma$ ). The ability of AM to reduce areas of ulceration was dose dependent, with the beneficial effect of AM waning somewhat at higher doses (Fig. 3c).

We further evaluated the effects of AM and its mechanism of action in dextran sulfate sodium (DSS)-induced colitis, a popular experimental model of UC, focusing on epithelial barrier function $[33,34]$. Control mice given DSS developed profound and sustained weight loss with symptoms of diarrhea and hematochezia (a major symptom of colitis) whereas body weight was maintained and clinical symptoms were suppressed in mice treated with AM. Histological analysis of tissue samples collected from control mice on day 10 after DSS administration revealed remarkable thickening of the colonic wall with pronounced crypt abscesses, 
endothelial erosions, and destroyed epithelial integrity. In contrast, the mice treated with AM exhibited far less severe histological manifestations, although the colon wall had become mildly thickened. Intestinal intraepithelial T lymphocytes (IELs) are essential for maintaining epithelial function and preventing inflammatory responses, and we found that IELs isolated from the large intestine of AM-treated mice consistently produced less IFN- $\gamma$, TNF- $\alpha$, and IL- 6 than those from control mice, and that production of transforming growth factor- $\beta$ (TGF- $\beta$ ) was induced. The induction of DSS colitis leads to changes in IEL profiles, with a relative decrease in the numbers of T cell receptor (TCR) $\gamma \delta+$ cells that express TGF- $\beta$ and might suppress inflammation by acting as regulatory $\mathrm{T}$ cells. Treating mice with AM prevents the TCR $\gamma \delta$ IEL population from becoming reduced, which would in turn inhibit the production of inflammatory cytokines and increase the production of TGF- $\beta$, thus suppressing signal transducer and activator of transcription (STAT)-3 and STAT-1 activation in epithelial cells. The mRNA expression of junctional molecules that contribute to the structure and function of tight junctions is obviously reduced in DSS colitis. However, such a reduction is much smaller in AM-treated mice, which might contribute to the suppression of the disease trajectory.

AM also exerts potent activity against various bacteria $[35,36]$ - for example, Escherichia coli-and the fact that the AM distribution within the mucosa is very similar to that of the defensin family of proteins [36] suggests that AM may also help defend against infection. In addition, the gastrointestinal tracts of AM-treated mice contain significantly fewer bacterial anaerobes than those of control mice [33]. The numbers of facultative anaerobes reportedly correlate with IBD activity in humans [37] and thus AM may protect against disruption of the mucosal epithelium through the suppression and translocation of anaerobes in the intestinal mucosa.

Reports from other laboratories also suggest that AM exerts beneficial effects against experimental models of colitis. For example, AM suppresses the inflammatory response and mediates the partial regeneration of mucosal immune tolerance in a model of TNBS-induced colitis, which reflects severe IBD [38]. In addition, $\mathrm{AM}$ is an efficient counter-regulatory agent that protects and improves the microcirculation that becomes adversely affected by cyclooxygenase (COX)-2 and inducible nitric oxide synthase (iNOS)/NO abnormalities during inflammation $[39,40]$. Hayashi et al. recently reported that AM ameliorates DSS-induced colitis, possibly via suppression of the systemic and local production of cytokines, such as TNF- $\alpha$ and IL-6, which accelerate ulcer healing and colonic mucosal regeneration [41]. AM also appears to reduce inflammatory indices and histological inflammation in DSS-induced murine colitis, and these beneficial effects are associated with mucosal protection through the fine tuning of hypoxia-induced factor (HIF) activity [42].

Given its effectiveness in these experimental models of colitis, we suggest that AM has potential as a novel agent for the treatment of IBD, and that it works by exerting anti-inflammatory and antibacterial effects and by stimulating mucosal regeneration and helping to maintain the colonic epithelial barrier. 


\section{Exploratory Clinical Study of AM as a Therapeutic Agent for Refractory Ulcerative Colitis}

AM confers benefits upon patients with cardiovascular diseases such as myocardial infarction, congestive heart failure, hypertension, pulmonary hypertension, and limb ischemia. The first clinical pilot study of intravenous AM in patients with acute myocardial infarction [43] found that an infusion of $12.5-25 \mathrm{ng} / \mathrm{kg} / \mathrm{min}$ of AM for $12 \mathrm{~h}$ did not significantly affect the hemodynamic parameters of the patients, but significantly improved the wall motion index in infarct areas at 3 months postinfarction, compared with baseline. Intravenously infused AM thus appears to exert potentially protective cardiovascular effects without severe adverse effects, which allows it to serve as a possible adjunct to percutaneous coronary intervention.

We found that AM infusions cause similar and steady decreases in blood pressure (Fig. 4a) and several markers of arteriosclerosis (such as pulse wave velocity) in patients with essential hypertension and primary aldosteronism (PA) [44, 45]. The infused AM suppressed aldosterone release to values within the normal range in the PA group, but had limited effect in the control group and did not alter adrenocorticotropic hormone-cortisol system in both groups (Fig. 4b). An infusion of AM $(15 \mathrm{ng} / \mathrm{kg} / \mathrm{min})$ induced an increase of circulating C-reactive protein (CRP) in all participants, which suggests that AM can inhibit or stimulate inflammation, depending upon the milieu. Consistent with this notion, AM downregulates TNF- $\alpha$, an important mediator of cytokine production, in macrophages and Swiss 3 T3 cells [18, 19], but stimulates IL-6 production in NR8383 and Swiss 3 T3 cells [46, 47]. Furthermore, bell-shaped dose-response curves (Fig. 3c) suggest that the beneficial effect of AM on ulcerative area is dose dependent, and that this effect tends to wane at higher doses. This means that an AM dose of $15 \mathrm{ng} / \mathrm{kg} / \mathrm{min}$ is too high for treating

a

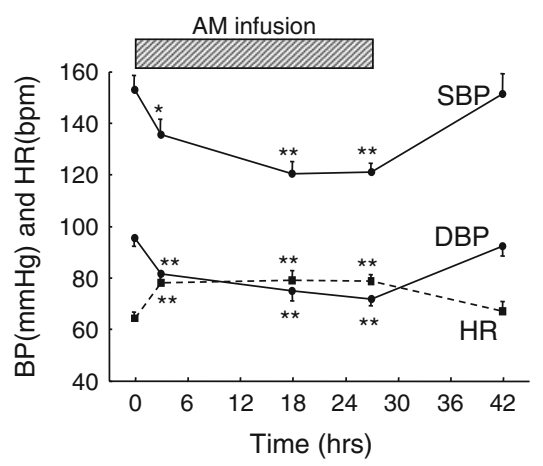

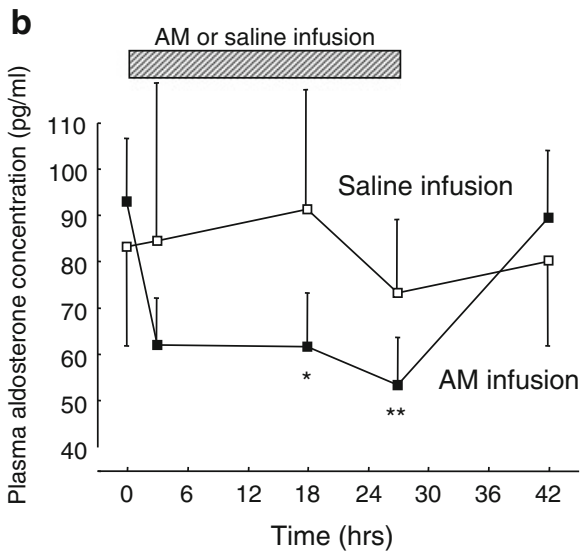

Fig. 4 Changes in blood pressure (a) and plasma aldosterone levels (b) during infusion of AM or vehicle in patients with essential hypertension and primary aldosteronism (Modified and redrawn from Ashizuka et al. [48]) 
IBD. Therefore, we clinically treated UC by administering AM at a dose of $9 \mathrm{ng} / \mathrm{kg} /$ min, which does not evoke severe hypotension or stimulate CRP production. Below, we describe the first patient with UC whom we treated using AM. The excellent results indicated that AM can effectively treat refractory UC [48, 34].

A 68-year-old woman who was undergoing treatment for diabetes presented with a 3-year history of refractory UC. During previous flare-ups, clinical remission was achieved using a high-dose steroid infusion and leukocytapheresis, but insufficient mucosal repair required a regimen of continuous prednisolone (PSL) with azathioprine (AZA). However, the patient's condition worsened, with symptoms of severe abdominal pain and bloody stools. Colonoscopy revealed deep ulcerations and erosions throughout the large intestine (Fig. 5a). Higher doses of PSL in combination with leukocytapheresis failed to induce remission (Ulcerative Colitis Disease Activity Index (UCDAI) score:7). After ischemic heart disease, cerebrovascular disease, and malignancy were ruled out, AM (9 ng/ $/ \mathrm{kg} / \mathrm{min})$ was intravenously administered for 12 days ( $8 \mathrm{~h} /$ day), which alleviated the abdominal pain and bloody stool after a few days. No adverse effects occurred except for a slight decline in blood pressure. Colonoscopy 2 weeks later revealed significant mucosal regeneration (Fig. 5b), which gastroenterologists had never encountered before, and the patient's UCDAI score had declined to 2. Colonoscopy 3 months later revealed that

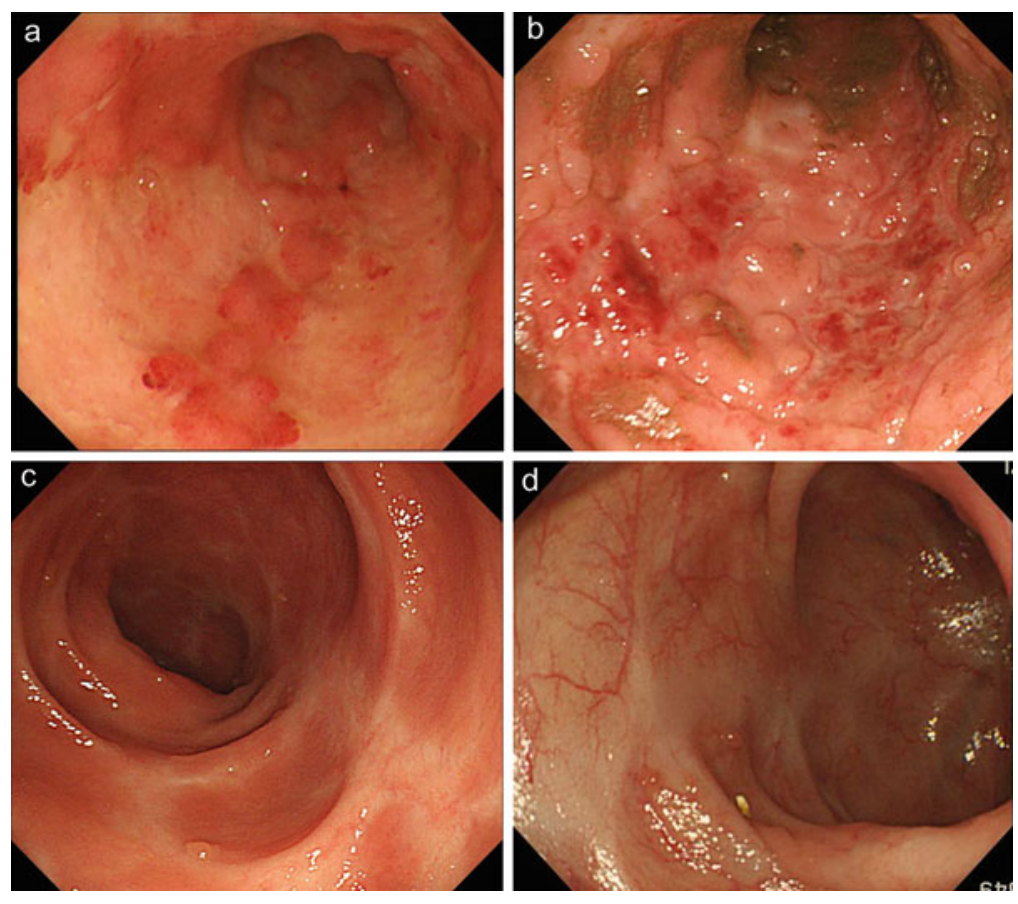

Fig. 5 Colonoscopy findings: (a) before; (b) 2 weeks after; (c) 3 months after; and (d) 12 months after treatment with AM (Modified from Ashizuka et al. [48]) 
all of the colonic lesions had healed with scarring and the patient's UCDAI score had reached 0, which prompted withdrawal of the PSL (Fig. 5a). Thus, AM appears to be effective against refractory UC in animal models of colitis and for patients with refractory UC.

Table 1 summarizes the comparison of AM therapy and existing methods currently used to treat IBD that all act through the induction and maintenance of remission [2, 34]. These include aminosalicylates (5-ASA), steroids (prednisolone), immune modifiers (azathioprine, 6-MP and methotrexate), and biologics (inflix-

Table 1 Comparison of AM therapy and methods currently used to treat IBD

\begin{tabular}{|c|c|c|c|}
\hline Agent & Mechanism & Merit & Demerit \\
\hline $\begin{array}{l}\text { Anti-inflammatory } \\
\text { agent }\end{array}$ & $\begin{array}{l}\text { Inhibition of LTB4 } \\
\text { production }\end{array}$ & \multirow[t]{2}{*}{ Safety } & \multirow[t]{2}{*}{$\begin{array}{l}\text { Insufficient for severe } \\
\text { UC }\end{array}$} \\
\hline SASP/5-ASA & $\begin{array}{l}\text { Removal of reactive } \\
\text { oxygen }\end{array}$ & & \\
\hline Hormonal agent & $\begin{array}{l}\text { Inhibition of inflammatory } \\
\text { cytokines }\end{array}$ & \multirow[t]{3}{*}{$\begin{array}{l}\text { Potent anti- } \\
\text { inflammatory } \\
\text { effect }\end{array}$} & $\begin{array}{l}\text { Cumulative toxicity } \\
\text { (metabolic } \\
\text { abnormality) }\end{array}$ \\
\hline \multirow[t]{2}{*}{ Predonisolone } & $\begin{array}{l}\text { Inhibition of cell } \\
\text { proliferation and } \\
\text { differentiation }\end{array}$ & & \multirow[t]{2}{*}{$\begin{array}{l}\text { Susceptibility to } \\
\text { infection }\end{array}$} \\
\hline & $\begin{array}{l}\text { Inhibition of cell } \\
\text { infiltration }\end{array}$ & & \\
\hline Immunosuppressor & $\begin{array}{l}\text { Inhibition of DNA } \\
\text { synthesis }\end{array}$ & \multirow[t]{3}{*}{$\begin{array}{l}\text { Maintenance of } \\
\text { remission }\end{array}$} & Myelosuppression \\
\hline \multirow[t]{2}{*}{ Azathioprine/6MP } & \multirow[t]{2}{*}{ Immunosuppressor } & & $\begin{array}{l}\text { Susceptibility to } \\
\text { infection }\end{array}$ \\
\hline & & & Malignant lymphoma? \\
\hline Immunosuppressor & \multirow[t]{3}{*}{ Inhibition of IL-2 } & \multirow{3}{*}{$\begin{array}{l}\text { Potent anti- } \\
\text { inflammatory } \\
\text { effect }\end{array}$} & $\begin{array}{l}\text { Monitoring the } \\
\text { concentration in blood }\end{array}$ \\
\hline \multirow[t]{2}{*}{$\begin{array}{l}\text { Cyclosporine, } \\
\text { Tacrolims }\end{array}$} & & & $\begin{array}{l}\text { Susceptibility to } \\
\text { infection }\end{array}$ \\
\hline & & & $\begin{array}{l}\text { Finger tremor, Renal } \\
\text { damage }\end{array}$ \\
\hline \multirow[t]{2}{*}{ Anti-cytokine agent } & \multirow[t]{3}{*}{ Anti-TNF- $\alpha$} & \multirow{3}{*}{$\begin{array}{l}\text { Potent anti- } \\
\text { inflammatory } \\
\text { effect }\end{array}$} & Tachyphylaxis, Allergy \\
\hline & & & $\begin{array}{l}\text { Susceptibility to } \\
\text { infection (tuberculosis) }\end{array}$ \\
\hline $\begin{array}{l}\text { Infliximab, } \\
\text { Adalimumab }\end{array}$ & & & Malignant lymphoma? \\
\hline $\begin{array}{l}\text { Blood component } \\
\text { removal }\end{array}$ & \multirow[t]{2}{*}{$\begin{array}{l}\text { Removal of activated } \\
\text { leukocyte }\end{array}$} & \multirow[t]{2}{*}{ Safety } & $\begin{array}{l}\text { Delayed effect } \\
(\sim 2 \text { weeks })\end{array}$ \\
\hline LCAP/GMA & & & Troublesome \\
\hline Endogenous peptide & Mucosal healing & Safety & \multirow[t]{3}{*}{ Hypotensive effect } \\
\hline \multirow[t]{2}{*}{ Adrenomedullin } & $\begin{array}{l}\text { Inhibition of inflammatory } \\
\text { cytokines }\end{array}$ & \multirow[t]{2}{*}{ New mechanism } & \\
\hline & $\begin{array}{l}\text { Angiogenesis, } \\
\text { Amelioration of ischemia }\end{array}$ & & \\
\hline
\end{tabular}


imab). However, the results obtained with these medications are not completely satisfactory in about one quarter of UC patients, as their effects are either insufficient or lead to complications. Surgical treatment (colectomy) may be considered for such patients.

In addition to conventional steroid therapy, immune modifiers or biologics are commonly used to treat steroid-resistant or steroid-dependent refractory UC. Although these therapies can be effective, potentially serious infections such as fungal diseases and tuberculosis are a concern, especially in patients with diabetes mellitus. In addition, immune modifiers can cause malignant lymphoma in young patients. Therefore, new and effective drugs that lack these adverse side effects are highly desirable. We found that a continuous intravenous infusion of AM ameliorated the symptoms of intractable UC without adverse side effects. Moreover, endoscopic evaluation after AM therapy showed remarkable mucosal regeneration and healing with neovascularization at previously ulcerative or erosive lesions. These results suggest that AM is a potentially useful therapeutic agent with a novel mechanism of action that involves anti-inflammatory effects with mucosal and vascular regeneration.

\section{Conclusion}

Here, we have provided general information about AM, its physiological and pathophysiological roles in the gastrointestinal tract, and translational research demonstrating the safety and value of AM for treating refractory UC. AM is a multifunctional cardiovascular hormone that exerts curative effects on cardiocirculatory dynamics. Thus, AM has been investigated mainly in the context of cardiovascular disease. However, AM can also protect organs and regenerate tissues, and it exerts anti-inflammatory and angiogenic effects while stimulating epithelial and mucosal cell proliferation. This suggests that AM could help to treat various diseases in addition to cardiovascular disease. With respect to its use in the treatment of refractory $\mathrm{UC}$, AM has no antigenicity because it is an endogenous peptide. Moreover, its mode of action differs from those of existing immunomodulators such as steroids, immune modifiers, and biologics. Additional study is required to confirm whether or not AM could treat refractory UC.

Acknowledgments This study was supported in part by the 8th Specified Research Grant from the Uehara Memorial Foundation; Grants-in-Aid for Scientific Research from the Ministry of Education, Culture, Sports, Science and Technology of Japan; and Health and Labor Science Research Grants for Translational Research from the Ministry of Health, Labor and Welfare, Japan.

Open Access This chapter is distributed under the terms of the Creative Commons Attribution Noncommercial License, which permits any noncommercial use, distribution, and reproduction in any medium, provided the original author(s) and source are credited. 


\section{References}

1. Latella G, Papi C (2012) Crucial steps in the natural history of inflammatory bowel disease. World J Gastroenterol: WJG 18(29):3790-3799. doi:10.3748/wjg.v18.i29.3790

2. Engel MA, Khalil M, Neurath MF (2012) Highlights in inflammatory bowel disease-from bench to bedside. Clin Chem Lab Med: CCLM/FESCC 50(7):1229-1235

3. Kitamura K, Kangawa K, Kawamoto M, Ichiki Y, Nakamura S, Matsuo H, Eto T (1993) Adrenomedullin: a novel hypotensive peptide isolated from human pheochromocytoma. Biochem Biophys Res Commun 192(2):553-560. doi:10.1006/bbrc.1993.1451

4. Cheung BM, Tang F (2012) Adrenomedullin: exciting new horizons. Recent Pat Endocr Metab Immune Drug Discovery 6(1):4-17

5. Ishimitsu T, Kojima M, Kangawa K, Hino J, Matsuoka H, Kitamura K, Eto T, Matsuo H (1994) Genomic structure of human adrenomedullin gene. Biochem Biophys Res Commun 203(1):631-639. doi:10.1006/bbrc.1994.2229

6. Hong Y, Hay DL, Quirion R, Poyner DR (2012) The pharmacology of adrenomedullin 2/intermedin. Br J Pharmacol 166(1):110-120. doi:10.1111/j.1476-5381.2011.01530.x

7. McLatchie LM, Fraser NJ, Main MJ, Wise A, Brown J, Thompson N, Solari R, Lee MG, Foord SM (1998) RAMPs regulate the transport and ligand specificity of the calcitonin-receptor-like receptor. Nature 393(6683):333-339. doi:10.1038/30666

8. Kitamura K, Sakata J, Kangawa K, Kojima M, Matsuo H, Eto T (1993) Cloning and characterization of cDNA encoding a precursor for human adrenomedullin. Biochem Biophys Res Commun 194(2):720-725. doi:10.1006/bbrc.1993.1881

9. Asada Y, Hara S, Marutsuka K, Kitamura K, Tsuji T, Sakata J, Sato Y, Kisanuki A, Eto T, Sumiyoshi A (1999) Novel distribution of adrenomedullin-immunoreactive cells in human tissues. Histochem Cell Biol 112(3):185-191

10. Minamino N, Kikumoto K, Isumi Y (2002) Regulation of adrenomedullin expression and release. Microsc Res Tech 57(1):28-39. doi:10.1002/jemt.10048

11. Kuwasako K, Kitamura K, Nagata S, Hikosaka T, Takei Y, Kato J (2011) Shared and separate functions of the RAMP-based adrenomedullin receptors. Peptides 32(7):1540-1550. doi:10.1016/j.peptides.2011.05.022

12. Ohta H, Tsuji T, Asai S, Tanizaki S, Sasakura K, Teraoka H, Kitamura K, Kangawa K (1999) A simple immunoradiometric assay for measuring the entire molecules of adrenomedullin in human plasma. Clin Chim Acta; Int J Clin Chem 287(1-2):131-143

13. Hirayama N, Kitamura K, Imamura T, Kato J, Koiwaya Y, Tsuji T, Kangawa K, Eto T (1999) Molecular forms of circulating adrenomedullin in patients with congestive heart failure. J Endocrinol 160(2):297-303

14. Kato J, Kobayashi K, Etoh T, Tanaka M, Kitamura K, Imamura T, Koiwaya Y, Kangawa K, Eto T (1996) Plasma adrenomedullin concentration in patients with heart failure. J Clin Endocrinol Metab 81(1):180-183. doi:10.1210/jcem.81.1.8550749

15. Ohta H, Tsuji T, Asai S, Sasakura K, Teraoka H, Kitamura K, Kangawa K (1999) One-step direct assay for mature-type adrenomedullin with monoclonal antibodies. Clin Chem 45(2):244-251

16. Nishio K, Akai Y, Murao Y, Doi N, Ueda S, Tabuse H, Miyamoto S, Dohi K, Minamino N, Shoji H, Kitamura K, Kangawa K, Matsuo H (1997) Increased plasma concentrations of adrenomedullin correlate with relaxation of vascular tone in patients with septic shock. Crit Care Med 25(6):953-957

17. Ueda S, Nishio K, Minamino N, Kubo A, Akai Y, Kangawa K, Matsuo H, Fujimura Y, Yoshioka A, Masui K, Doi N, Murao Y, Miyamoto S (1999) Increased plasma levels of adrenomedullin in patients with systemic inflammatory response syndrome. Am J Respir Crit Care Med 160(1):132-136. doi:10.1164/ajrccm.160.1.9810006

18. Isumi Y, Kubo A, Katafuchi T, Kangawa K, Minamino N (1999) Adrenomedullin suppresses interleukin-1beta-induced tumor necrosis factor-alpha production in Swiss 3 T3 cells. FEBS Lett 463(1-2):110-114 
19. Kamoi H, Kanazawa H, Hirata K, Kurihara N, Yano Y, Otani S (1995) Adrenomedullin inhibits the secretion of cytokine-induced neutrophil chemoattractant, a member of the interleukin-8 family, from rat alveolar macrophages. Biochem Biophys Res Commun 211(3):1031-1035. doi:10.1006/bbrc.1995.1914

20. Gonzalez-Rey E, Chorny A, O'Valle F, Delgado M (2007) Adrenomedullin protects from experimental arthritis by down-regulating inflammation and Th1 response and inducing regulatory T cells. Am J Pathol 170(1):263-271. doi:10.2353/ajpath.2007.060596

21. Onur OE, Guneysel O, Akoglu H, Denizbasi A, Onur E (2007) Adrenomedullin reduces the severity of cerulein-induced acute pancreatitis. Peptides 28(11):2179-2183. doi:10.1016/j. peptides.2007.08.028

22. Matsui E, Kitamura K, Yoshida M, Kato J, Asada Y, Sumiyoshi A, Eto T (2001) Biosynthesis and secretion of adrenomedullin and proadrenomedullin $\mathrm{N}$-terminal 20 peptide in a rat model of endotoxin shock. Hypertens Res: Off J Jpn Soc Hypertens 24(5):543-549

23. Saito R, Shimosawa T, Ogihara T, Maruyama N, Fujita T, Okamura N, Nakahara K (2012) Function of adrenomedullin in inflammatory response of liver against LPS-induced endotoxemia. APMIS: Acta Pathol Microbiol Immunol Scand 120(9):706-711. doi:10.1111/j.1600-0463.2012.02892.x

24. Shindo T, Kurihara H, Maemura K, Kurihara Y, Kuwaki T, Izumida T, Minamino N, Ju KH, Morita H, Oh-hashi Y, Kumada M, Kangawa K, Nagai R, Yazaki Y (2000) Hypotension and resistance to lipopolysaccharide-induced shock in transgenic mice overexpressing adrenomedullin in their vasculature. Circulation 101(19):2309-2316

25. Washimine H, Asada Y, Kitamura K, Ichiki Y, Hara S, Yamamoto Y, Kangawa K, Sumiyoshi A, Eto T (1995) Immunohistochemical identification of adrenomedullin in human, rat, and porcine tissue. Histochem Cell Biol 103(4):251-254

26. Hashimoto H, Akimoto M, Maeda A, Shigemoto M, Yamashita K, Yokoyama I (2000) Changes in vasoactive substances during gastric ulcer healing. J Cardiovasc Pharmacol 36(5 Suppl 1):S278-S281

27. Cantarella G, Martinez G, Cutuli VM, Loreto C, D'Alcamo M, Prato A, Amico-Roxas M, Bernardini R, Clementi G (2005) Adrenomedullin modulates COX-2 and HGF expression in reserpine-injuried gastric mucosa in the rat. Eur J Pharmacol 518(2-3):221-226. doi:10.1016/j. ejphar.2005.06.001

28. Hirsch AB, McCuen RW, Arimura A, Schubert ML (2003) Adrenomedullin stimulates somatostatin and thus inhibits histamine and acid secretion in the fundus of the stomach. Regul Pept 110(3):189-195

29. Hikosaka T, Tsuruda T, Nagata S, Kuwasako K, Tsuchiya K, Hoshiko S, Inatsu H, Chijiiwa K, Kitamura K (2011) Adrenomedullin production is increased in colorectal adenocarcinomas; its relation to matrix metalloproteinase-9. Peptides 32(9):1825-1831. doi:10.1016/j.peptides.2011.07.012

30. Kim JY, Park WD, Lee S, Park JH (2012) Adrenomedullin is involved in the progression of colonic adenocarcinoma. Mol Med Rep 6(5):1030-1034. doi:10.3892/mmr.2012.1045

31. Ashizuka S, Ishikawa N, Kato J, Yamaga J, Inatsu H, Eto T, Kitamura K (2005) Effect of adrenomedullin administration on acetic acid-induced colitis in rats. Peptides 26(12):2610-2615. doi:10.1016/j.peptides.2005.05.007

32. Kojima R, Hamamoto S, Moriwaki M, Iwadate K, Ohwaki T (2001) [The new experimental ulcerative colitis model in rats induced by subserosal injection of acetic acid]. Nihon Yakurigaku Zasshi Folia Pharmacol Jpn 118(2):123-130

33. Ashizuka S, Inagaki-Ohara K, Kuwasako K, Kato J, Inatsu H, Kitamura K (2009) Adrenomedullin treatment reduces intestinal inflammation and maintains epithelial barrier function in mice administered dextran sulphate sodium. Microbiol Immunol 53(10):573-581. doi:10.1111/j.1348-0421.2009.00159.x

34. Ashizuka S, Inatsu H, Inagaki-Ohara K, Kita T, Kitamura K (2013) Adrenomedullin as a potential therapeutic agent for inflammatory bowel disease. Curr Protein Pept Sci 14(4):246-255

35. Marutsuka K, Nawa Y, Asada Y, Hara S, Kitamura K, Eto T, Sumiyoshi A (2001) Adrenomedullin and proadrenomudullin N-terminal 20 peptide (PAMP) are present in human colonic epithelia and exert an antimicrobial effect. Exp Physiol 86(5):543-545 
36. Allaker RP, Grosvenor PW, McAnerney DC, Sheehan BE, Srikanta BH, Pell K, Kapas S (2006) Mechanisms of adrenomedullin antimicrobial action. Peptides 27(4):661-666. doi:10.1016/j.peptides.2005.09.003

37. Cummings JH, Macfarlane GT, Macfarlane S (2003) Intestinal bacteria and ulcerative colitis. Curr Issues Intest Microbiol 4(1):9-20

38. Gonzalez-Rey E, Fernandez-Martin A, Chorny A, Delgado M (2006) Therapeutic effect of urocortin and adrenomedullin in a murine model of Crohn's disease. Gut 55(6):824-832. doi:10.1136/gut.2005.084525

39. Talero E, Alvarez de Sotomayor M, Sanchez-Fidalgo S, Motilva V (2011) Vascular contribution of adrenomedullin to microcirculatory improvement in experimental colitis. Eur J Pharmacol 670(2-3):601-607. doi:10.1016/j.ejphar.2011.09.032

40. Talero E, Sanchez-Fidalgo S, de la Lastra CA, Illanes M, Calvo JR, Motilva V (2008) Acute and chronic responses associated with adrenomedullin administration in experimental colitis. Peptides 29(11):2001-2012. doi:10.1016/j.peptides.2008.07.013

41. Hayashi Y, Narumi K, Tsuji S, Tsubokawa T, Nakaya MA, Wakayama T, Zuka M, Ohshima T, Yamagishi M, Okada T (2011) Impact of adrenomedullin on dextran sulfate sodium-induced inflammatory colitis in mice: insights from in vitro and in vivo experimental studies. Int $\mathrm{J}$ Colorectal Dis 26(11):1453-1462. doi:10.1007/s00384-011-1254-0

42. MacManus CF, Campbell EL, Keely S, Burgess A, Kominsky DJ, Colgan SP (2011) Antiinflammatory actions of adrenomedullin through fine tuning of HIF stabilization. FASEB J: Off Publ Fed Am Soc Exp Biol 25(6):1856-1864. doi:10.1096/fj.10-170316

43. Kataoka Y, Miyazaki S, Yasuda S, Nagaya N, Noguchi T, Yamada N, Morii I, Kawamura A, Doi K, Miyatake K, Tomoike H, Kangawa K (2010) The first clinical pilot study of intravenous adrenomedullin administration in patients with acute myocardial infarction. J Cardiovasc Pharmacol 56(4):413-419. doi:10.1097/FJC.0b013e3181f15b45

44. Kita T, Suzuki Y, Kitamura K (2010) Hemodynamic and hormonal effects of exogenous adrenomedullin administration in humans and relationship to insulin resistance. Hypertens Res: Off J Jpn Soc Hypertens 33(4):314-319. doi:10.1038/hr.2009.236

45. Kita T, Tokashiki M, Kitamura K (2010) Aldosterone antisecretagogue and antihypertensive actions of adrenomedullin in patients with primary aldosteronism. Hypertens Res: Off J Jpn Soc Hypertens 33(4):374-379. doi:10.1038/hr.2010.8

46. Isumi Y, Minamino N, Kubo A, Nishimoto N, Yoshizaki K, Yoshioka M, Kangawa K, Matsuo H (1998) Adrenomedullin stimulates interleukin-6 production in Swiss 3 T3 cells. Biochem Biophys Res Commun 244(2):325-331. doi:10.1006/bbrc.1998.8261

47. Wong LY, Cheung BM, Li YY, Tang F (2005) Adrenomedullin is both proinflammatory and antiinflammatory: its effects on gene expression and secretion of cytokines and macrophage migration inhibitory factor in NR8383 macrophage cell line. Endocrinology 146(3):13211327. doi:10.1210/en.2004-1080

48. Ashizuka S, Kita T, Inatsu H, Kitamura K (2013) Adrenomedullin: a novel therapy for intractable ulcerative colitis. Inflamm Bowel Dis 19(2):E26-E27. doi:10.1002/ibd.22891 